\title{
Pengaruh Profitabilitas, Growing Asset, Company Size terhadap Structure Value Equity pada Property Company dan Real Perdagangan yang Terdaftar di Bursa Efek Indonesia Periode 2014-2016
}

\section{Leo Mas Prayatna}

leovinzz7@gmail.com

Dwi Jaka Andarikha

jakandarikha18@gmail.com

Jennica

jennicawu123@gmail.com

Anita

xie_anita@yahoo.com

Engela Fransisca

engelafrans@gmail.com

Sauh Hwee Teng

tengsauhhwee@unprimdn.ac.id

\section{William}

Leesekhun1@gmail.com

\begin{abstract}
Abstrak Penelitian ini bertujuan untuk menguji dan menganalisis Pengaruh Profitabilitas, Growing Asset, Company Size terhadap Structure Value Equity pada Property Company \& Real Perdagangan yang terdaftar di Bursa Efek Indonesia Periode 2014-2016. Pendekatan penelitian yang digunakan dalam adalah pendekatan kuantitatif dengan sifat hubungan antar variabel. Populasi dalam penelitian ini adalah seluruh perusahaan Property Company dan Real Perdagangan yang terdaftar di Bursa Efek Indonesia (BEI) sebanyak 42 perusahaan. Dari populasi tersebut terdapat 18 perusahaan yang dipilih dengan menggunakan metode purposive sampling. Dalam penelitian ini teknik analisis yang digunakan adalah analisis regresi linear berganda. Berdasarkan hasil uji hipotesis secara simultan, diperoleh pengaruh signifikan terhadap Structure Value Equity, dengan hasil uji koefisien determinasi sebesar $18,9 \%$. Sedangkan berdasarkan hasil uji hipotesis secara parsial, Profitabilitas, Growing Asset tidak berpengaruh signifikan terhadap Structure Value Equity dan Company Size berpengaruh positif dan signifikan terhadap Structure Value Equity.
\end{abstract}

Kata Kunci Profitabilitas, Growing Asset, Company Size, Structure Value Equity 


\begin{abstract}
This study aims to examine and analyze the Influence of Profitability, Growing Asset, Company Size towards Structure Value Equity of Property \& Real Estate Company Listed on the Indonesia Stock Exchange (IDX) for the 2014-2016 period. The research approach used in this study is quantitative approach with relationship between variables. The population in this study were 42 Property \& Real Estate companies listed on the Indonesia Stock Exchange (IDX). From this population there are 18 companies selected using the purposive sampling method. In this study the analysis technique used is multiple linear regression analysis. Based on the results of simultaneous hypothesis testing, obtained a significant effect on Structure Value Equity, with the test results of the determination coefficient of 18.9\%. While based on the results of partial hypothesis testing, Profitability and Growing Asset did not significantly affect Structure Value Equity and Company Size had a positive and significant effect on Structure Value Equity.
\end{abstract}

\title{
Keywords Profitability, Growing Asset, Company Size, Structure Value Equity
}

\section{PENDAHULUAN}

Pasar modal merupakan salah satu roda perekonomian suatu Negara, yang mana direpesentasikan dalam dua fungsi, yakni sebagai sarana pendanaan usaha dan sebagai sarana bagi perusahaan mendapatkan dana dari masyarakat pemodal. Perusahaan property \& real estate saat ini sangat mengalami kemajuan, dangan banyaknya pembangunan yang masih dikerjakan sampai sekarang. Salah satu faktor yang membuat perusahaan property semakin maju adalah banyaknya permintaan pasar terhadap sektor ini dengan banyaknya bangunan seperti apartemen, hotel dan perkantoran yang masih dibangun sampai sekarang dan ini diperkirakan akan terus berkelanjutan. Namun di samping itu setiap bangunan yang akan dibangun akan berdiri diatas tanah, tidak akan pernah bertambah dikarenakan pertambahan jumlah penduduk serta bertambahnya kebutuhan manusia akan tempat tinggal,pusat perbelanjaan, perkantoran dan taman hiburan dan yang lainnya, ini akan membuat permintaan lebih tinggi daripada penawaran dan akan memicu naiknya harga di sektor property.

Perusahaan yang memiliki profitabilitas yang tinggi cenderung untuk menggunakan hutang terlebih dahulu dan relatif lebih besar dalam struktur modalnya agar mendapatkan keuntungan dari pajak, karena pembayaran bunga hutang dapat mengurangi beban pajak yang harus dibayar perusahaan sehingga ada penghematan membayar pajak. Pertumbuhan aset merupakan kemampuan perusahaan untuk meningkatan size. Pertumbuhan aset pada dasarnya di pengaruhi oleh beberapa faktor, yaitu faktor eksternal, internal dan pengaruh iklim lokal. Perusahaan dengan tingkat pertumbuhan yang rendah sebaiknya menggunakan hutang sebagai sumber pembiayaannya, karena penggunaan hutang akan mengharuskan perusahaan tersebut membayar bunga secara teratur. Ukuran perusahaan merupakan faktor yang sangat penting dalam meningkatkan struktur modal pada perusahaan itu sendiri, dikarenakan ukuran perusahaan itu menggambarkan besar 
atau kecilnya suatu aset yang dimiliki perusahaan tersebut. Bagi investor akan lebih memilih menanamkan modalnya kepada perusahaan yang sudah besar dan mapan dibandingkan pada perusahaan kecil. Ukuran perusahaan dapat mempengaruhi struktur modal, karena semakin besar suatu perusahaan akan cenderung membutuhkan pendanaan yang lebih besar pula.

Struktur modal menunjukkan jumlah modal dan hutang yang dimiliki oleh perusahaan yang digunakan untuk menjalankan aktivitas perushaan. Dengan mengetahui angka rasio hutang yang dimiliki perusahaan, para investor dapat menganalisis struktur perusahaan. Kasus yang paling sering terjadi adalah tidak tepatnya pengelolaan struktur modal yang berasal dari hutang. Sebagian besar perusahaan cenderung untuk terbiasa bergantung pada hutang. Komposisi utang menjadi meningkat. Masalah terbesar yang dapat terjadi ketika struktur modal tidak dapat dikelola dengan baik, maka akan terjadi kebangkrutan atau berkurangnya kemampuan perusahaan untuk bertahan hidup. Oleh karena itu, pengelolaan struktur modal sangat penting dilaksanakan.

\section{LANDASAN TEORI}

\section{Pengertian Profitabilitas}

Menurut Sartono (2012: 122), profitabilitas adalah kemampuan perusahaan memperoleh laba dalam hubungannya dengan penjualan, total aktiva, maupun modal sendiri.

Menurut Fahmi (2016: 80), rasio profitabilitas adalah rasio ini mengukur efektivitas manajemen secara keseluruhan yang diperoleh dalam hubungannyadengan penjualan maupun investasi.

Menurut Kasmir (2015: 196), rasio profitabilitas merupakan rasio untuk menilai kemampuan perusahaan dalam mencari keuntungan.

Berdasarkan pengertian di atas dapat disimpulkan bahwa profitabilitas merupakan laba yang dihasilkan suatu perusahaan.

\section{Pengertian Pertumbuhan Aset (Growth Asset)}

Menurut Hartono (2013: 421), variable pertumbuhan aktiva (Asset Growth) didefinisikan sebagai perubahan (tingkat pertumbuhan) tahunan dari aktiva nol.

Menurut Jumingan (2014: 122), rasio pertumbuhan perusahaan adalah rasio yang menggambarkan kemampuan perusahaan dalam mempertahankan kedudukannya dalam pertumbuhan perekonomian dan industri

Menurut Fahmi (2016: 82), rasio yang menggambarkan kemampuan perusahaan dalam mempertahankan posisi ekonominya di tengah pertumbuhan ekonomi dann sektor usahanya.

Dari beberapa pengertian diatas dapat disimpulkan bahwa pertumbuhan asset adalah kemampuan aktiva perusahaan dalam kesempatan pengembangan dan kebutuhan dana yang dikelola terhadap jumlah return yang dihasilkan.

\section{Pengertian Ukuran Perusahaan}

Menurut Riyanto (2010: 299), suatu perusahaan yang besar dimana sahamnya tersebar sangat luas, setiap perusahaan sahamnya hanya akan mempunyai pengaruh yang kecil terhadap kemungkinan hilangnya atau terserangnya kontrol dari pihak dominan terhadap perusahaan yang bersangkutan. 
Menurut Sitanggang (2013: 76), ukuran perusahaan dengan kapitalisasi pasar atau penjualan yang besar menunjukkan prestasi perusahaan. Perusahaan yang besar akan lebih mudah mendapatkan akses ke sumber dana untuk memperoleh tambahan modal dengan utang.

Menurut Mulyawan (2015: 247), firm size dapat didefinisikan sebagai logaritma dari net sales. Ini berarti ukuran dari suatu perusahaan dapat diketahui dari jumlah penjualan bersih yang dimiliki perusahaan.

Dari pengertian di atas dapat disimpulkan bahwa ukuran perusahaan adalah kekayaan yang dimiiki perusahaan berupa benda berwujud maupun tidak berwujud.

\section{Faktor-faktor yang mempengaruhi Profitabilitas}

Terdapat beberapa faktor yang mempengaruhi perubahan profitabilitas. Menurut Jumingan (2014: 165), faktor-faktor yang mempengaruhi perubahan profitabilitas yaitu naik-turunnya jumlah unit, naik-turunnya harga pokok penjulan, naik-turunnya biaya usaha, naik-turunnya pos penghasilan atau biaya non-operasional, naik-turunnya pajak perseroan, dan adanya perubahan dalam metode akuntansi

Profitabilitas mempunyai arti penting dalam melangsungkan kehidupan suatu perusahaan. Profitabilitas dapat memprediksi tingkat pengembalian perusahaan tinggi atau rendah dilihat dari sisi utang yang dipinjam.

\section{Pertumbuhan Aset (Growth Asset)}

Terdapat beberapa faktor yang mempengaruhi pertumbuhan aset. Menurut Kasmir (2015 : 107), faktor-faktor yang mempengaruhi pertumbuhan aset yaitu pertumbuhan penjualan, pertumbuhan laba bersih, pertumbuhan pendapatan per saham dan pertumbuhan dividen per saham.

Pada pertumbuhan aset dapat disimpulkan semakin tinggi pertumbuhan aset, maka semakin banyak menggunakan utang sebagai pendanaannya.

\section{Ukuran Perusahaan}

Menurut Hery (2014: 52), ukuran perusahaan dapat digolongkan sebagai salah satu unsur dari lingkungan kerja yang akan turut mempengaruhi persepsi manajemen nantinya.

Ukuran perusahaan adalah semakin besar suatu perusahaan maka akan semakin tinggi tingkat modal yang diperolehnya dan sebaliknya.

\section{Teori pengaruh Profitabilitas terhadap Struktur Modal}

Menurut Sartono ( 2012: 248), profitabilitas merupakan faktor penting dalam menentukan struktur modal. Dengan laba ditahan yang besar, perusahaan akan lebih cenderung menggunakan laba ditahan sebelummenggunakan hutang.

\section{Pertumbuhan Aset (Growth Asset) terhadap Struktur Modal}

Menurut Atmaja (2009: 299 ), perusahaan dengan tingkat pertumbuhan yang tinggi cenderung menggunakan banyak hutang di banding dengan perusahaan dengan tingkat pertumbuhan rendah.

\section{Ukuran Perusahaan terhadap Struktur Modal}


Menurut Mulyawan (2015: 247), ukuran perusahaan mengindikasikan bahwa semakin besar suatu perusahaan, semakin besar pula tingkat hutangnya.

\section{Arti Penting Profitablitas}

Menurut Harmono (2017: 109), analisis profitabilitas perusahaan, analisis profitablitas ini menggambarkan kinerja fundamental perusahaan ditinjau dari tingkat efisiensi dan efektivitas operasi perusahaan dalam memperoleh laba.

\section{Arti Penting Pertumbuhan Aset (Growth Asset)}

Menurut Riyanto (2010: 4), setiap rupiah dana yang tertanam dalam aktiva harus dapat digunakan seefisien mungkin untuk dapat menghasilkan tingkat keuntungan investasi yang maksimal.

\section{Arti Penting Ukuran Perusahaan}

Menurut Hartono (2013: 422), ukuran aktiva dipakai sebagai wakil pengukur (proxy) besarnya perusahaan. Perusahaan yang besar dianggap mempunyai resiko yang lebih kecil dibandingkan dengan perusahaan yang lebih kecil.

\section{METODOLOGI PENELITIAN}

Pendekatan penelitian ini bersifat kuantitatif. Menurut Sugiyono (2017: 8), penelitian kuantatif dapat diartikan sebagai metode penelitian yang berlandaskan pada filsafat positivisme, digunakan untuk meneliti pada populasi atau sampel tertentu, pengumpulan data menggunakan instrumen penelitian, analisis data bersifat kuantatif/statistik, dengan tujuan untuk menguji hipotesis yang telah ditetapkan.

\section{HASIL PENELITIAN}

\section{Uji Normalitas}

Uji Normalitas bertujuan untuk menguji apakah dalam model regresi, variabel pengganggu atau residul memiliki distribusi normal. Kalau uji normalitas ini di langgar maka uji statistik menjadi tidak valid untuk jumlah sampel yang kecil. Hasil uji normalitas histogram dan P-P Plot dapat dilihat pada gambar berikut ini :

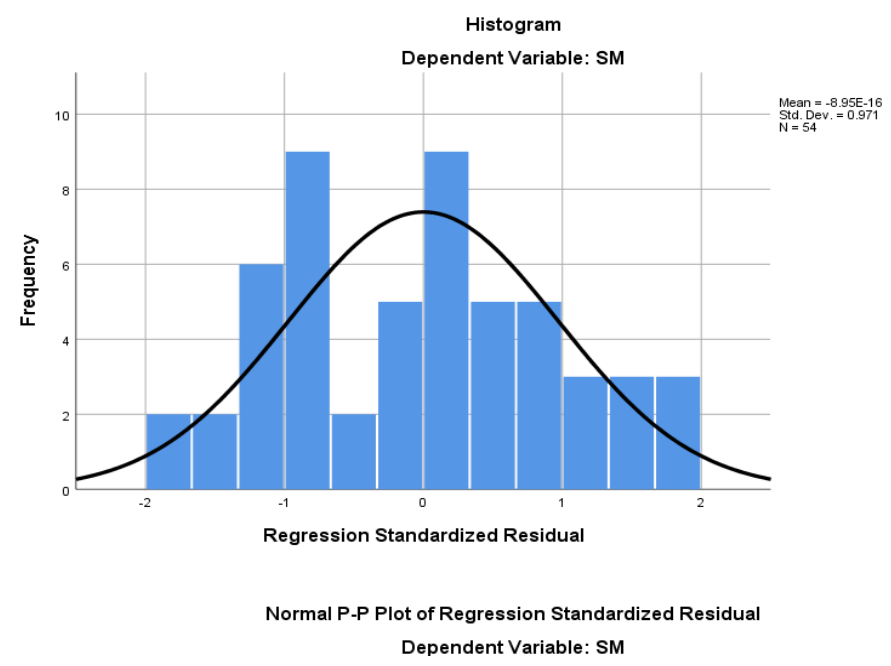

Gambar 4.1 Normalitas 
Grafik Histogram pada Gambar IV.1 di atas menunjukkan garis kurva cenderung simetri (U) maka dapat dikatakan data berdistribusi normal. Hasil uji normalitas P-P Plot dapat dilihat pada gambar berikut ini :

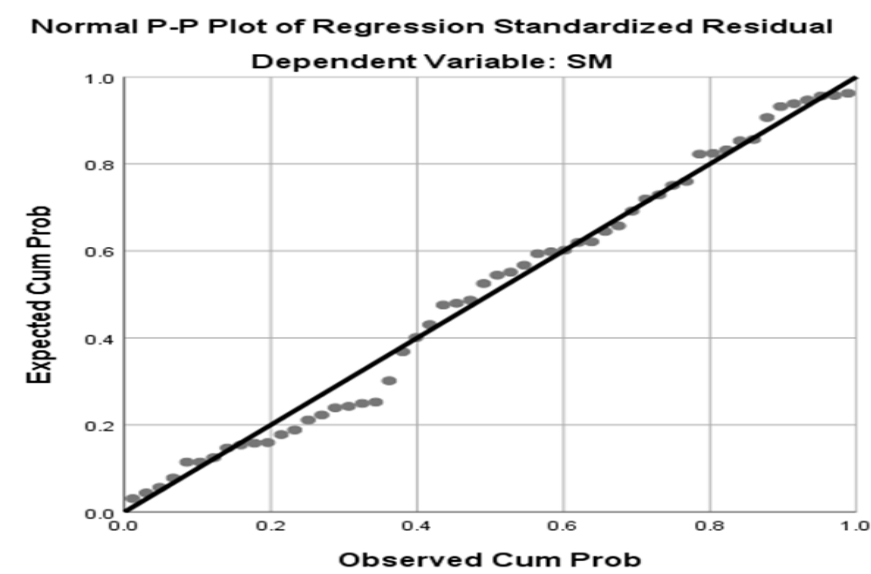

Gambar 4.2 Grafik P - P Plot

Grafik Normalitas P-P Plot pada Gambar IV.2 di atas, terlihat titik-titik menyebar mendekati garis diagonal. Selain analisis grafik perlu dilakukan analisis statistik untuk memastikan apakah data benar-benar telah terdistribusi normal. Pengujian secara statistik apabila nilai signifikasi lebih besar dari 0,05 maka dapat dikatakan data berdistribusi normal. Hasil uji dapat dilihat pada tabel berikut ini :

\section{Tabel 4.1 Uji Kolmogorov Smirnov}

One-Sample Kolmogorov-Smirnov Test

\begin{tabular}{|c|c|c|}
\hline & & $\begin{array}{l}\text { Unstandardiz } \\
\text { ed Residual }\end{array}$ \\
\hline N & & 54 \\
\hline \multirow[t]{2}{*}{ Normal Parameters ${ }^{a, b}$} & Mean & .0000000 \\
\hline & Std. Deviation & .44171213 \\
\hline \multirow[t]{3}{*}{ Most Extreme Differences } & Absolute & .106 \\
\hline & Positive & .106 \\
\hline & Negative & -.052 \\
\hline Test Statistic & & .106 \\
\hline Asymp. Sig. (2-tailed) & & $.197^{\circ}$ \\
\hline
\end{tabular}

Sumber : Hasil Olahan Data, 2019

Hasil uji normalitas Kolmogrov smirnov menunjukkan nilai signifikan 0,197 > 0,05 dengan demikian hasil uji normalitas Kolomogorov Smirnov dapat diambil kesimpulan data berdistribusi normal. 


\section{Uji Multikolinearitas}

Uji Multikolinearitas bertujuan untuk menguji apakah pada model regresi ditemukan adanya korelasi antar variabel independen. Pada model regresi yang baik seharusnya tidak terjadi korelasi antar variabel independen.

\section{Tabel 4.2 Uji Multikolinearitas}

\section{Coefficients $^{\mathrm{a}}$}

\begin{tabular}{|c|c|c|c|}
\hline \multirow[b]{2}{*}{ Mode } & & \multicolumn{2}{|c|}{ Collinearity Statistics } \\
\hline & & Tolerance & VIF \\
\hline \multirow[t]{4}{*}{1} & (Constant) & & \\
\hline & $\mathrm{P}$ & .903 & 1.107 \\
\hline & GA & .918 & 1.089 \\
\hline & UP & .943 & 1.061 \\
\hline
\end{tabular}

a. Dependent Variable: SM

\section{Sumber : Hasil Olahan Data, 2019}

Pengujian Multikolinearitas sebelum transformasi pada model regresi tidak terjadi korelasi antar independen karena nilai tolerance variabel profitabilitas, pertumbuhan aset, ukuran perusahaan dan struktur modal sebelum transformasi berada di atas 0,10 sedangkan nilai VIF variabel profitabilitas, pertumbuhan aset, ukuran perusahaan dan struktur modal sebelum transformasi berada dibawah 10 .

\section{Uji Autokorelasi}

Pada penelitian ini, uji autokorelasi dilakukan dengan menggunakan uji DurbinWatson. Menurut Sunyoto (2013: 98) salah satu ukuran dalam menentukan ada tidaknya masalah autokorelasi dengan uji Durbin-Watson (DW) dengan ketentuan sebagai berikut :

1. Terjadi autokorelasi positif nilai D-W dibawah -2 (DW <-2)

2. Tidak terjadi autokorelasi jika nilai $\mathrm{D}-\mathrm{W}$ berada diantara -2 dan +2 atau $-2<\mathrm{DW}\rangle$ $+2$

3. Tidak terjadi autokorelasi negatif jika nilai $\mathrm{D}-\mathrm{W}$ di atas +2 atau $\mathrm{DW}>+2$ 


\section{Tabel 4.3 Uji Durbin Watson}
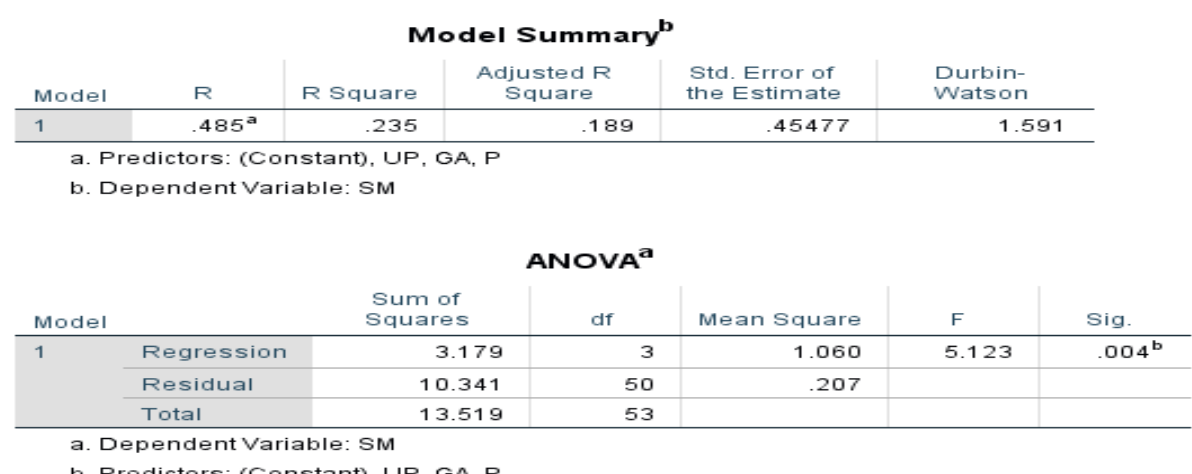

\section{Sumber : Hasil Olahan Data, 2019}

Dari hasil uji autokorelasi sebelum transformasi diperoleh nilai Durbin-Watson sebesar 1.591; maka dapat disimpulkan bawah Durbin-Watson test tidak ada autokorelasi karena nilai $-2<1,591<2$

\section{Uji Heteroskedastisitas}

Suatu model regresi yang baik adalah tidak terjadi heteroskedastisitas. Ada beberapa cara menguji ada tidaknya situasi heteroskedastisitas dalam varian eror terms untuk model regresi. Dalam penelitian ini akan digunakan metode Chart (Diagram Scatterplot), dengan dasar pemikiran bahwa : 1) Jika ada pola tertentu seperti titik-titik (poin-poin), yang ada membentuk suatu pola tertentu yang beraturan (bergelombang, melebar, kemudian menyempit), maka terjadi heteroskedastisitas. 2) Jika ada pola yang jelas, serta titik-titik menyebar ke atas dan di bawah 0 pada sumbu $Y$ maka tidak terjadi heteroskedastisitas.

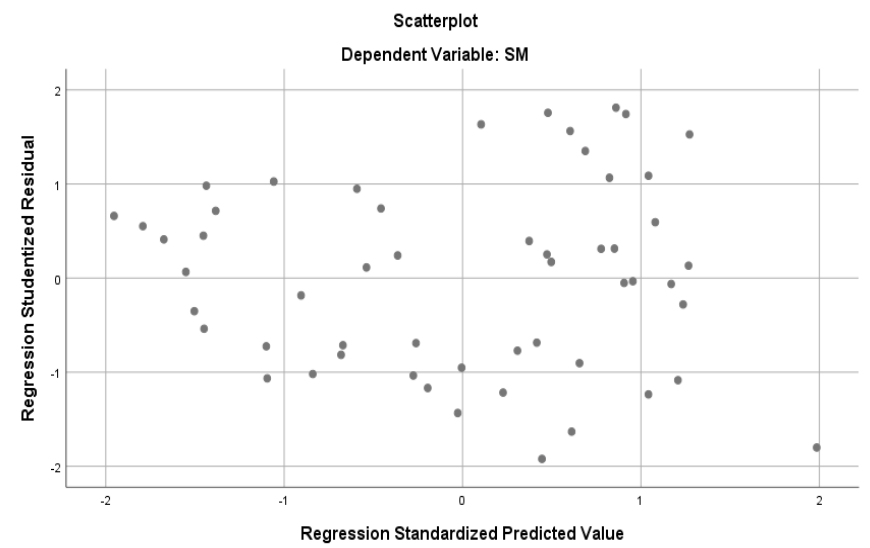

\section{Gambar 4.1 Heteroskedastisitas}

Dari grafik scatterplot terlihat bahwa titik-titik menyebar secara acak tersebar baik di atas maupun di bawah angka nol (0) pada sumbu Y, tidak berkumpul di satu tempat, sehingga dari grafik scatterplot dapat disimpulkan bahwa tidak terjadi heteroskedastisitas pada model regresi. 
Pendeteksian ada tidaknya heteroskedastisitas bisa juga dilakukan dengan menggunakan Uji Glejser, dilakukan meregres nilai absolut residul terhadap variabel independen.

\section{Tabel 4.4 Uji Glejser}

\begin{tabular}{|c|c|c|c|c|c|c|c|c|}
\hline \multicolumn{9}{|c|}{ Coefficients $^{a}$} \\
\hline & & \multicolumn{2}{|c|}{ Unstandardized Coefficients } & \multirow{2}{*}{$\begin{array}{c}\text { Standardized } \\
\text { Coefficients } \\
\text { Beta }\end{array}$} & \multirow[b]{2}{*}{$t$} & \multirow[b]{2}{*}{ Sig. } & \multicolumn{2}{|c|}{ Collinearity Statistics } \\
\hline \multicolumn{2}{|c|}{ Model } & $\mathrm{B}$ & Std. Error & & & & Tolerance & VIF \\
\hline \multirow[t]{4}{*}{1} & (Constant) & $-4.194 \mathrm{E}-16$ & .796 & & .000 & 1.000 & & \\
\hline & $\mathrm{P}$ & .000 & 1.356 & .000 & .000 & 1.000 & .903 & 1.107 \\
\hline & GA & .000 & .527 & .000 & .000 & 1.000 & .918 & 1.089 \\
\hline & UP & .000 & .026 & .000 & .000 & 1.000 & .943 & 1.061 \\
\hline
\end{tabular}

\section{Sumber : Hasil Olahan Data, 2019}

Hasil Uji Glejser sebelum transformasi pada tabel 4.4 di atas menunjukkan nilai signifikan dari 3 buah variabel independen yaitu Profitabilitas, Pertumbuhan Aset dan Ukuran Perusahaan $>0.05$. Hal ini terlihat dari signifikasinya di atas kepercayaaan $5 \%$. Jadi dapat disimpulkan model regresi tidak mengandung adanya heteroskedastisitas.

\section{Hasil Analisis Data Penelitian}

Model penelitian ini menggunakan pengujian hipotesis yang dalam penelitian ini adalah dengan menggunakan analisis regresi linier berganda. Model regresi yang digunakan adalah sebagai berikut :

\section{Tabel 4.5 Model Regresi Linear Berganda}

\begin{tabular}{|c|c|c|c|c|c|c|c|c|}
\hline \multicolumn{9}{|c|}{ Coefficients $^{a}$} \\
\hline \multirow[b]{2}{*}{ Model } & & \multicolumn{2}{|c|}{ Unstandardized Coefficients } & \multirow{2}{*}{$\begin{array}{c}\text { Standardized } \\
\text { Coefficients } \\
\text { Beta } \\
\end{array}$} & \multirow[b]{2}{*}{$\mathrm{t}$} & \multirow[b]{2}{*}{ Sig. } & \multicolumn{2}{|c|}{ Collinearity Statistics } \\
\hline & & B & Std. Error & & & & Tolerance & VIF \\
\hline \multirow[t]{4}{*}{1} & (Constant) & -.538 & .796 & & -.677 & .502 & & \\
\hline & $P$ & -3.885 & 1.356 & -.373 & -2.865 & .006 & .903 & 1.107 \\
\hline & GA & .982 & .527 & .240 & 1.863 & .068 & .918 & 1.089 \\
\hline & UP & .053 & .026 & .257 & 2.017 & .049 & .943 & 1.061 \\
\hline
\end{tabular}

a. Dependent Variable: SM

$$
\mathrm{SM}=-0,538-0,3885 \mathrm{P}+0,982 \mathrm{GA}+0,053 \mathrm{UP}
$$

Makna dari persamaan regresi linier berganda diatas adalah:

1. Konstan sebesar -0,538 menyatakan bahwa jika profitabilitas, pertumbuhan aset, dan ukuran perusahaan bernilai konstantan atau 0 maka struktur modal perusahaan property dan real estate sebesar $-0,538$.

2. Koefisien regresi profitabilitas sebesar $-3,885$ menyatakan bahwa setiap kenaikan 1 satuan variabel profitabilitas akan menyebabkan penurunan struktur modal sebesar -3,885 dengan anggapan variabel lainnya konstan. 
3. Koefisien regresi pertumbuhan aset sebesar 0,982 menyatakan bahwa setiap kenaikan 1 variabel pertumbuhan aset akan menyebabkan kenaikan struktur modal sebesar 0982 dengan anggapan variabel lainnya konstan.

4. Koefisien regresi ukuran perusahan sebesar 0,053 menyatakan bahwa setiap kenaikan 1 variabel ukuran perusahaan akan menyebabkan kenaikan strutur modal sebesar 0,053 dengan anggapan variable lainnya konstan.

\section{Koefisien Determinasi Hipotesis}

Koefisien determinasi ditujukan untuk mengetahui seberapa besar kemampuan model dalam menerangkan variabel terikat. Jika koefisien determinasi $\left(\mathrm{R}^{2}\right)$ semakin besar atau mendekati 1, maka dapat dikatakan bahwa kemampuan variabel bebas $(\mathrm{X})$ adalah besar terhadap variabel terikat $(\mathrm{Y})$.

\section{Tabel 4.6 Uji Koefisien Determinasi}

\begin{tabular}{|c|c|c|c|c|c|}
\hline \multicolumn{6}{|c|}{ Model Summary } \\
\hline Model & $\mathrm{R}$ & R Square & $\begin{array}{c}\text { Adjusted R } \\
\text { Square }\end{array}$ & $\begin{array}{l}\text { Std. Error of } \\
\text { the Estimate }\end{array}$ & $\begin{array}{l}\text { Durbin- } \\
\text { Watson }\end{array}$ \\
\hline 1 & $.485^{\mathrm{a}}$ & .235 & .189 & .45477 & 1.591 \\
\hline
\end{tabular}

\section{Sumber : Hasil Olahan Data, 2019}

Hasil Uji Koefisien Determinasi setelah transformasi diperoleh nilai $R$ square sebesar 0,485 hal ini berarti 48,5\% dari variansi variabel dependen struktur modal yang dapat dijelaskan oleh variabel indepeden profitabilitas, pertumbuhan aset dan ukuran perusahaan sedangkan sisanya sebesar 51,5\% (100\% - 48,5\%) dijelaskan oleh variabelvariabel lain diluar variabel penelitian.

\section{Pengujian Hipotesis Secara Simultan}

Uji $\mathrm{F}$ digunakan untuk menunjukkan apakah semua variabel independen yang dimasukkan dalam model mempunyai pengaruh secara bersama-sama terhadap variabel dependen.

\section{Tabel 4.7 Uji F}

\begin{tabular}{|c|c|c|c|c|c|c|}
\hline \multicolumn{7}{|c|}{ ANOVA $^{a}$} \\
\hline Model & & $\begin{array}{l}\text { Sum of } \\
\text { Squares }\end{array}$ & df & Mean Square & $\mathrm{F}$ & Sig. \\
\hline \multirow[t]{3}{*}{1} & Regression & 3.179 & 3 & 1.060 & 5.123 & $.004^{b}$ \\
\hline & Residual & 10.341 & 50 & .207 & & \\
\hline & Total & 13.519 & 53 & & & \\
\hline
\end{tabular}

Sumber : Hasil Olahan Data, 2019 
Uji Signifikansi simultan / bersama-sama (uji statistik F) menghasilkan nilai F hitung sebesar 5,123. Pada derajat bebas $1\left(\mathrm{df}_{1}\right)=\mathrm{k}-1=4-1=3$, dan derajat bebas $2\left(\mathrm{df}_{2}\right)=\mathrm{n}$ $-\mathrm{k}=54-3=51$, dimana $\mathrm{n}=$ jumlah sampel, $\mathrm{k}=$ jumlah variabel, nilai $\mathrm{f}$ tabel pada taraf kepercayaan signifikansi 0,05 adalah 2,79 dengan demikia $\mathrm{F}$ hitung $=5,123>\mathrm{F}$ tabel $=$ 2,79 dengan tingkat signifikansi 0,000

Maka $\mathrm{H}_{a}$ diterima artinya secara bersama-sama ptofitabilitas, pertumbuhan aset dan ukuran perusahaan berpengaruh terhadap struktur modal pada perusahaan property dan real estate yang terdaftar di Bursa Efek Indonesia periode 2014-2016.

\section{Pengujian Hipotesis Secara Parsial}

Pengujian t-test digunakan untuk menunjukkan seberapa jauh pengaruh satu variabel independen terhadap variabel independen.

\section{Tabel 4.8 Uji t}

\begin{tabular}{|c|c|c|c|c|c|c|c|c|}
\hline \multicolumn{9}{|c|}{ Coefficients $^{a}$} \\
\hline \multirow[b]{2}{*}{ Model } & & \multicolumn{2}{|c|}{ Unstandardized Coefficients } & \multirow{2}{*}{$\begin{array}{c}\text { Standardized } \\
\text { Coefficients } \\
\text { Beta }\end{array}$} & \multirow[b]{2}{*}{ t } & \multirow[b]{2}{*}{ Sig. } & \multicolumn{2}{|c|}{ Collinearity Statistics } \\
\hline & & B & Std. Error & & & & Tolerance & VIF \\
\hline \multirow[t]{4}{*}{1} & (Constant) & -.538 & .796 & & -.677 & .502 & & \\
\hline & $\mathrm{P}$ & -3.885 & 1.356 & -.373 & -2.865 & .006 & .903 & 1.107 \\
\hline & GA & .982 & .527 & .240 & 1.863 & .068 & .918 & 1.089 \\
\hline & UP & .053 & .026 & .257 & 2.017 & .049 & .943 & 1.061 \\
\hline
\end{tabular}

\section{Sumber : Hasil Olahan Data, 2019}

Berdasarkan tabel 4.8 di atas dapat disimpulkan bahwa:

1. Hasil perhitungan uji $\mathrm{t}$ secara parsial diperoleh nilai $\mathrm{t}$ hitung profitabilitas sebesar 2,865 dengan nilai signifikan sebesar 0,006. Nilai -t hitung - $t$ tabel $-2,865>-2,00758$ maka $\mathrm{Ha}$ artinya profitabilitas berpengaruh negatif terhadap struktur modal pada perusahaan property dan real estate yang terdaftar di Bursa Efek Indonesia periode 2014-2016.

2. Hasil perhitungan uji t secara parsial diperoleh nilai t hitung pertumbuhan aset sebesar 1,883 dengan nilai signifikan sebesar 0,068. Nilai t hitung t tabel 1,883 $<2,00758$ maka Ho artinya pertumbuhan aset tidak berpengaruh terhadap struktur modal pada perusahaan property dan real estate yang terdaftar di Bursa Efek Indonesia periode 2014-2016.

3. Hasil perhitungan uji $\mathrm{t}$ secara parsial diperoleh nilai t hitung ukuran perusahaan sebesar 2,017 dengan nilai signifikan sebesar 0,049. Nilai t hitung t tabel 2,017 > 2,00758 maka Ha ukuran perusahaan tidak berpengaruh terhadap struktur modal pada perusahaan property dan real estate yang terdaftar di Bursa Efek Indonesia periode 2014-2016. 


\section{Pembahasan Hasil Penelitian \\ Pengaruh Profitabilitas Terhadap Struktur Modal}

Dari hasil pengolahan data diperoleh nilai -t hitung > -t tabel atau -2,865> -2,00758 dengan demikian $\mathrm{H} 1$ yang menyatakan profitabilitas berpengaruh terhadap struktur modal pada perusahaan property dan real estate yang terdaftar di Bursa Efek Indonesia periode 2014-2016 tidak dapat diterima.

bahwa kemampuan perusahaan menghasilkan laba merupakan faktor penting dalam menentukan faktor modal. Dengan laba ditahan yang besar, perusahaan akan lebih senang menggunakan laba diatahan sebelum menggunakan hutang atau menerbitkan saham baru. (Riyanto, 2010: 297)

Hasil penelitian ini tidak sejalan dengan hasil penelitian Ida Bagus Made Dwija Bhawa dan Made Ruslama Dewi(2015) yaitu profitibilitas berpengaruh negatif signifikan terhadap struktur modal.

\section{Pengaruh Pertumbuhan Aset Terhadap Struktur Modal}

Dari hasil pengolahan data diperoleh nilai t hitung $<\mathrm{t}$ tabel 1,883 $<2,00758$ dengan demikian $\mathrm{H} 2$ yang menyatakan pertumbuhan aset berpengaruh positif dan signifikan terhadap struktur modal pada perusahaan property dan real estate yang terdaftar di Bursa Efek Indonesia periode 2014-2016 tidak dapat diterima

Semakin cepat petumbuhan perusahaan, maka semakin besar kebutuhan dana untuk pembiayaan ekspansi. Semakin besar kebutuhan untuk pembiayaan mendatang maka, semakin besar keinginan perusahaan untuk menahan laba. (Sartono, 2012: 248)

Hasil penelitian ini tidak sejalan dengan hasil penelitian Fatimuz Zuhro MB(2016) yaitu Pertumbuhan Aset berpengaruh tidak signifikan terhadap struktur modal

\section{Pengaruh Ukuran Perusahaan Terhadap Struktur Modal}

Dari hasil pengolahan data diperoleh nilai t hitung t tabel 2,017 > 2,00758 dengan demikian $\mathrm{H} 3$ yang menyatakan ukuran perusahaan berpengaruh positif dan signinifikan terhadap struktur modal pada perusahaan property dan real estate yang terdaftar di Bursa Efek Indonesia periode 2014-2016 dapat diterima.

Ukuran perusahaan mengindikasikan bahwa semakin besar suatu perusahaan, semakin besar pula tingkat hutangnya.(Mulyawan, 2015: 247)

Hasil penelitian ini sejalan dengan hasil penelitian Sri Hermuningsih (2012) yaitu ukuran perusahaan berpengaruh positif terhadap struktur modal

\section{KESIMPULAN}

Kesimpulan dari hasil penelitian ini adalah:

1. Secara simultan profitabilitas, pertumbuhan aset, dan ukuran perusahaan berpengaruh terhadap struktur modal pada perusahaan property dan real estate yang terdaftar di Bursa Efek Indonesia periode 2014 - 2016 dengan hasil uji koefisien determinasi diperoleh $48,5 \%$ dari variasi dependen struktur modal yang dapat dijelaskan oleh variabel independen profitabilitas, pertumbuhan aset, dan ukuran perusahaan.

2. Secara parsial profitabilitas berpengaruh negatif terhadap struktur modal pada perusahaan property dan real estate yang terdaftar di Bursa Efek Indonesia periode 2014-2016. 
3. Secara parsial pertumbuhan aset tidak berpengaruh terhadap struktur modal pada perusahaan property dan real estate yang terdaftar di Bursa Efek Indonesia periode 2014-2016.

4. Secara parsial ukuran perusahaan tidak berpengaruh terhadap struktur modal pada perusahaan property dan real estate yang terdaftar di Bursa Efek Indonesia periode 2014-2016.

\section{Saran}

Saran dari hasil penelitian ini adalah:

1. Bagi perusahaan property dan real estate, agar manajemen memperhatikan laba bersih profitabilitas karena variabel ini dapat mempengaruhi struktur modal.

2. Bagi Universitas Prima Indonesia, agar mempublikasikan hasil penelitian ini supaya dapat digunakan sebagai acuan penelitian.

3. Bagi investor, apabila hendak berinvestasi pada perusahaan property dan real estate yang terdaftar di Bursa Efek Indonesia dapat melihat besarnya profitabilitas sebagai indikator faktor yang mempengaruhi struktur modal.

4. Bagi peneliti selanjutnya, disarankan untuk tidak menambah variabel penelitian karena hasil koefisien determinasi menunjukkan 18,9\% dari variasi variabel dependen struktur modal yang dapat dijelaskan oleh variabel di luar penelitian.

\section{DAFTAR PUSTAKA}

Bhawa dan Rusmala Dewi. (2015). Pengaruh Ukuran Perusahaan, Likuiditas, Profitabilitas, dan Resiko Bisnis Terhadap Struktur Modal Perusahaan Farmasi Di UNUD, Bali E-Jurnal Manajemen Unud, Vol. 4,07.

Fahmi, I. (2016). Pengantar Manajemen Keuangan Teori dan Soal Jawab. Cetakan Kelima. Bandung: Penerbit CV. Alfabeta

Fatimatuz, Z.MB. (2016). Pengaruh Ukuran Perusahaan, Pertumbuhan Aset dan Profitabilitas Terhadap Struktur Modal Di STIESIA, Surabaya Jurnal Ilmu dan Riset Manajemen. Vol. 5,08.

Ghozali, I. (2013). Aplikasi Analisis Multivariate Dengan Program SPSS. Semarang: Universitas Diponegoro.

Harahap, S.S. (2013). Analisis Kritis atas Laporan Keuangan. Cetakan Kesebelas. Jakarta: Penerbit PT. Raja GrafindoPersada.

Harmono. (2017). Manajemen Keuangan Berbasis Balanced scorecard Pendekatan Teori, Kasus, dan Riset Bisnis. Cetakan Keenam. Jakarta: Penerbit PT. Bumi Aksara.

Hartono, J. (2013). Teori Portofolio dan Analisis Investasi. Ed. 8, Cetakan Pertama.Yogyakarta: BPFE,2013

Hery. (2015). Analisis Laporan Keuangan .PT.Bumi Aksara, Jakarta 
Jumingan. (2014). Analisis Laporan Keuangan. Cetakan Kelima. Jakarta: Penerbit PT. Bumi Aksara.

Kasmir. (2015). Analisis Laporan Keuangan. Cetakan Kedelapan. Jakarta: Penerbit PT. Grafindo Persada.

Murhadi, W.R. (2013). Analisis Laporan keuangan Proyek dan Valuasi Saham. Jakarta: Penerbit Salemba Empat.

Mulyawan, S. (2015). Manajemen Keuangan. Cetakan Pertama. Bandung: Penerbit Pustaka Setia.

Riyanto, B. (2010). Dasar-Dasar Pembelanjaan Perusahaan. Cetakan Kedua Belas. Yogyakarta: Penerbit BPFE.

Sartono, A. (2012). Manajemen Keuangan Teori dan Aplikasi. Cetakan Keempat. Yogyakarta: Penerbit BPFE UGM.

Sitanggang, J.P. (2013). Manajemen Keuangan Perusahaan. Jakarta: Mitra Wacana Media.

Sjarial, D. (2007). Manajemen Keuangan Lanjutan. Jakarta: Mitra Wacana Media.

Sudana, I.M. (2011). Manajemen Keuangan Perusahaan: Teori \& Praktik. Jakarta: Penerbit Erlangga.

Sunyoto, D. (2013). Metologi Penelitian Akuntansi. Cetakan Kesatu.

Bandung: Penerbit PT. Refika Aditama.

Sugiyono. (2012). Metode Penelitian Bisnis. Bandung: CV Alfabeta.

Syaifullah. (2014). Buku Praktis Akuntansi Biaya \& Keuangan. Jakarta: Penerbit Laskar Aksara.

www.idx.co.id 